

Journal home page: geology-dnu-dp.ua

\title{
Media tourism in the Chernobyl Exclusion Zone as a new tourist phenomenon
}

\author{
O. P. Krupskyi, K.O. Temchur \\ Oles Honchar Dnipro National University, Dnipro, Ukraine, e-mail: krupskyy71@gmail.com
}

Received 12.06.2018;

Received in revised form 12.07.2018;

Accepted 30.07.2018

\begin{abstract}
Every year, the number of tourists in the Chernobyl Exclusion Zone is increasing. The most numerous visitors are journalists who come to perform their official duties. At the same time, researchers have not yet shown interest in such an interesting and important tourist phenomenon. The purpose of this article is to describe a new phenomenon of media tourism in the Chernobyl Exclusion Zone and its
\end{abstract} features. The study was conducted with a help of a qualitative case study analysis method. The websites of the state and private enterprises and mass media publications based on the results of trips to the territory for 2013-2017 were analyzed. As a result, the specific features of journalists who visit the Chernobyl Exclusion Zone were identified. Such journalists mainly have confidence in the absence of a threat to health (55\%), developed empathy (45\%) and imagination of thinking (45\%). Consequently, the tragedy of history and the gloomy appearance of the territory, the suffering of local residents make it attractive to journalists. In addition, due to personal interest, the voluntary travel motive $(61,5 \%)$ prevails over conditional forced travel $(38,5 \%)$. At the same time, the attention of journalists to the territory is attracted due to the activities of tourists. The authors describe the so-called «compensation effect», when the reduction of tourists' attention to the territory is balanced by an increase in the attention of the mass media. The presence of risk explains the predominance of men among journalists in the Chernobyl Exclusion Zone (54\%). For example, women can better assess the risk due to greater vulnerability. The peculiarity of journalists' work in the Chernobyl Exclusion Zone is the risk of radiation exposure and ethical controversy. The study shows that journalists' inherent positive world perception and profound sense of professional duty can successfully overcome these obstacles. The results of the study can be used by the following researchers to identify ways and strategies for promoting media tourism in the Chernobyl Exclusion Zone. The benefit of this study is to draw attention to a new unexplored tourist phenomenon. Mass media have a great influence on the formation of a positive attitude towards the territory and attracting the attention of tourists. Taking into account the specific features of media tourism will help to attract more tourists and improve the quality of rendering service to journalists.

Keywords: journalists, mass-media, tourism, Chernobyl exclusion zone.

\section{едійний туризм у орнобильській зоні відчуження як новий туристичний феномен}

$$
\text { . . рупський, . . емчур }
$$

нот ція. орічне збільшення туристичної ктивності у орнобильській зоні відчуження приверт є ув гу журн лістів до цієї території. ри цьому дослідники досі не виявили інтересу до цього феномену. ет ст тті - опис ти новий феномен медійного туризму у орнобильській зоні відчуження т його особливості. евивченість цього явищ змусил звернутися до якісного експлор тивного методу, який дозволяє опис ти новий феномен т н д ти м тері л для н стуних досліджень. ст тті опис но діяльність держ вного т прив тного підприємств з н д ння орг ніз ційно-інформ ційних послуг журн ліст м. 'ясов но особистісні якості журн лістів, які змушують їх здійснюв ти т ку поїздку. прикл д, перекон ність у відсутності з грози для здоров'я (55\%), зд тність співпережив ти (45\%) т обр зність мислення (45\%) приверт ють ув гу журн лістів до цієї території. ільше того, особист з цік вленість пояснює перев ж ння добровільного мотиву поїздки (61,5\%) н д умовно вимушеним ком ндирув нням (38,5\%). ст новлено, що серед журн лістів у перев ж ють чоловіки (54\%) через їхню меншу зд тність до оцінки ризику. 'ясов но особливості роботи журн лістів у орнобильській зоні відчуження, які відрізняють їі від роботи н інших територіях. х р кетризов но з кономірності зв'язку кількості публік цій м с-меді 3 описом туристичного досвіду т кількості туристів. втор ми опис но т к зв ний «ефект компенс ції», коли зменшення ув ги туристів до території компенсується збільшенням ув ги м с-меді . 
Introduction. The Chernobyl accident has caused the phenomenon of Chornobyl's journalism to come to life. The first visitors to Chernobyl after the explosion were precisely the journalists who performed the professional responsibility for documenting the scale and consequences of the accident (Kuzmych-Pohodenko, 2015).

By its number, representatives of the Ukrainian and foreign mass media are the second group of visitors after foreign scientists conducting research in the Chernobyl Exclusion Zone ( EZ) together with Ukrainian counterparts (Golovata, 2010).

Dark tourism, which includes tourism in the $\mathrm{EZ}$, is today a promising area. The term was first used by researchers J. Lennon and M. Foley to mark the tourist interest in places of recent deaths, catastrophes and crimes (Foley, Lennon, 1996). The CEZ is one of the most famous destinations of this type (Yankovska, Hannam, 2014). The fact that the authoritative economic edition Forbes recognized the Chernobyl Nuclear Power Plant ( hNPP) as one of the most exotic places for tourism in the world also contributes to the popularity of the territory among tourists (Forbes, 2009).

It should be noted that there is no unanimity among the researchers regarding the classification of journalists' travel in the EZ as tourists. Some researchers suggest classifying Chernobyl journalism as business tourism and emphasize the professional preconditions for such visits (Pestushko, Chubuk, 2010; Derkach, 2014). In this article we will follow this very approach, because often the purpose of journalists' travel to the EZ is to cover the tourist attractions of the infected area and its state within the limits of their professional activity. At the same time, mass media follow certain tourist routes, developed according to their professional interests. It is clear that journalists can come to excursions to the EZ as ordinary tourists. That is, such a trip will be carried out for recreational and cognitive purposes, and not within the framework of professional activity. Such visits can not be considered as media tourism and are not regarded in our article.

The scientific literature on the topic emphasizes the decisive role of the media in promoting dark tourism, in particular in the EZ (Butler, 1990; Kim, Richardson, 2003; Iwashita, 2006; Young; Young; 2008; Yankovska, Hannam, 2014). Other authors emphasize that the study of the phenomenon of Chernobyl's journalism, despite the significance of such activity, has not yet become relevant in scientific circles (Kuzmych-Pohodenko, 2015).

The urgency of the study is conditioned by the lack of research on media tourism in the EZ, as well as the growing popularity of tourism in the EZ.

The purpose of the study is to describe a new phenomenon of media tourism in the EZ and its features.

Accordingly, the following tasks are set:

- to analyze the activities of tourist enterprises and state institutions for organizing travel of journalists to the EZ;

- to analyze the materials of the media, prepared according to the results of visiting the EZ;

- to analyze the legal acts regulating the legal aspects of the activity in the EZ.

Methods and materials. This study was conducted with a help of a qualitative case study analysis method. R. Yin explains the usage of this method by the necessity to understand complex social phenomena and generalize them to make theoretical assumptions (Yin, 2009). Appeal to this method is justified by the insufficient attention of researchers to the phenomenon of media tourism in the EZ. This situation has led to the necessity to describe it and to provide the next researchers with material for quantitative research and testing of hypotheses.

For analysis, sites of two companies - the State Agency of Ukraine on Exclusion Zone Management (SAUEZM) (Derzhavne agentstvo Ukrai'ny z upravlinnja zonoju vidchuzhennja, 2018) and Chernobyl-tour (Chernobyl-tur, 2018) were selected. This choice was dictated by their exclusive role in the organization of tourism activities in the EZ. SAUEZM manages access to the EZ, makes the issuance of permits for all official visits and approves their programs. The State Enterprise «Technical and Information Support Management Center of the exclusion zone» (TISMCEZ), which is in the field of SAUEZM management, regulates tourism activity in the EZ. The function of the company is the organization of visits to CEZ for journalists of Ukrainian and foreign mass media and their information support.

The Kyiv Travel Agency «Chernobyl-tour» is a leading private travel agency that provides targeted organizational and information services to mass media representatives in the EZ. The information agency of the company cooperates with leading world mass media such as The Times, Forbes, Associated Press, BBC, Discovery, Lonely Planet and many others.

The search on the site SAUEZM for the keywords «tourism», «journalists» provided only 23 publications for the period 2016-2017 years. On the site of the travel agency «Chernobyl-tour»we were interested in the tabs «Information agency» and «Media and Chernobyl-tour». The content of these materials is directly connected with cooperation with journalists and reflects their tourism activ- 
ities in the EZ. In particular, in the «Media and Chernobyl-tour» tab, there are 9 mass media publications following the 2010-2016 trips.

The research of mass media publications took place during the year, starting from July 2017. We made a request to the Google search engine for the keywords «Chernobyl», «journalists». So the search was limited by territorial and professional background. The criterion for selecting publications for research is their publication based on the results of the trip to the EZ. Only $20 \%$ of the publications met this criterion, while others were ignored. All investigated materials were exceptionally based on information resources. These materials can be divided into three thematic groups: coverage of the newsbreak, research of the current state of the territory and a description of the tourist trip. In total, 1300 pages of text, 75 hours of video, 29 forums were analyzed. All videos were transcribed, comments on the forums were collected manually and recorded.

For information on the dynamics of the journalists' visit to the CEZ over the past 5-10 years, we have sent a formal request to the SAUEZM. The answer is that there is no separate record of journalists' visits, that is why the requested information can not be provided. The corresponding request was also sent to the office of the tourist agency «Chernobyl-tour», but no replies were received.

We sought to find out whether an increase in tourist flows provokes the interest of the media or the publication attracts tourists to the territory. Successively we restricted the chronological range of search from January 1 to December 31, 2013, 2014, $2015,2016,2017$. The first 1,000 of the total volume of relevant results were investigated in each case. We guessed that only publications about tourist routes connected with tourist interest. Then we formed a theoretical sample of 10 materials in which the phenomenon studied is expressed in the purest and most transparent form (Eisenhardt, 1989). According to Eisenhardt, «the purpose of the theoretical sample is the selection of cases that can expand the emerging theory». This made it possible to verify that namely publications describing tourist experience are related with the dynamics of tourism flows. We have established a strong positive correlation between the number of visitors to the EZ and the number of available materials about this territory (the correlation coefficient is 0.8021 at $\mathrm{p}$ $<=$ (less or equal to 0.05). We cited quotes from these materials further for visibility of some of our conclusions.

We assumed that visiting the EZ requires a journalist to have certain characterological features. Our task was to make a portrait of such a journalist. We also wondered if there was a connection be- tween sex and interest in such visits. We encoded the following categories: (1) purpose - the reason for the trip; (2) motive - an impulse to travel (coercion or good will); (3) sexual affiliation (male, female); (4) character - the specific personality traits of journalists who visited the territory. The last category included those fragments of journalistic materials that clearly traced the manifestation of some aspect of the personality of the journalist. All encodings were manually processed in the Excel file. First, each of us analyzed the materials for these categories, after which we discussed the results and ideas that arose. Each of us got identical results, with the exception of the last category. We got both identical and different results.

At the second stage, we analyzed each publication by category (1) «positive world perception», (2) «confidence in the absence of a threat to health», (3) «profound sense of professional duty», (4) «curiosity», (5) «impressionability», (6), «inclination to sensationalism» (7), «developed empathy», (8) «household unpretentiousness», and (9) «imagination of thinking». Finally, we recorded the part of publications containing each of the categories. Our results were identical.

To verify the correctness of our study, we provided preliminary conclusions at each stage to experts in the field of economics and tourism management (Lincoln, Guba, 1985). The remarks made in each case were taken into account when necessary having gathered additional information on the topic (Alvesson, Kärreman, 2007). To confirm our assertions, we compared the obtained results with the typology developed by Myers-Briggs, which is used to determine the occupational inclination of individuals. Specific features of journalists in the CEZ correspond to their professional features. We also contacted the jobseekers websites Career Cast and Superjob, which empirically confirmed the inherent nature of the gender and personality traits of journalists in the EZ.

Results.Organizational aspect of media tourism in the EZ. Organizational activity of state enterprises. 2016 was declared a year in memory of the participants in the liquidation of the Chernobyl accident and the victims of the Chernobyl disaster, which dates back to the 30th anniversary of the tragedy. In connection with this, the SAUEZM together with the enterprises of the sphere of its management organized events for visitors. During these events, state institutions reported on the course of liquidation of the consequences of the accident, the work on reducing the radiation hazard, the results of the implementation of international projects, the current state of EZ, etc. (Derzhavne agentstvo Ukrai'ny z zapravlinnja zonoju vidchuzhennja, 2016). The necessity to attract the attention 
of the world community to the problems of EZ and liquidators has led to special measures for media workers. This led to a significant increase in journalists' tourism activity in the EZ.

On April 22, 2016, the SAUEZM together with the TISMCEZ organized a press tour (an event for journalists - excursion) for the representatives of the Ukrainian and foreign mass media. The purpose of the tour was to familiarize journalists with the work of enterprises, the status of implementation of international projects and the prospect of reforming the EZ. The journalists attended the briefing of the head of the agency, visited the observation deck of the Shelter Object to familiarize themselves with the progress of the construction of a new safe confinement, learned about the progress of work on the storage of spent nuclear fuel (ISF-2), talked with ChNPP chief engineer on its further functioning, and $t$ the end of the tour, they visited Pripyat, where they could see how the city changed over 30 years after the resettlement of residents (Derzhavne agentstvo Ukrainy $\mathrm{z}$ upravlinnja zonoju vidchuzhennja, 2016).

The commemoration of the 30th anniversary of the Chernobyl accident has attracted the attention of not only Ukrainian but also world media. At the end of February 2016, the EZ was visited by a crew of the Scottish office for the filming of the special program «Europe» for this date. The journalists set out to show the consequences of the accident and the changes that occurred after it. Accompanied by the specialists of the TISMCEZ, they interviewed the liquidators of the accident, got acquainted with the work of the measuring center «EcoCenter», visited the observation deck of the Shelter bject, the city of Pripyat. As a result of the trip, a 30-minute film was prepared (Derzhavne agentstvo Ukrainy z upravlinnja zonoju vidchuzhennja, 2016).

Organizational activity of private enterprises. The task of the staff of the tourist agency «Chernobyl-tour» is to make the journalists' visit to the EZ as comfortable and productive as possible. Their duties include organizing a working visit, conducting excursions for journalists, providing interviews, information on the Chernobyl accident and its consequences, the current state and prospects for the development of the EZ, providing advice on correct and scientifically accurate coverage of this information in the media. They also search for speakers for interviews, organize meetings with eyewitnesses and liquidators of the accident, «self-settlers», specialists ( EZ staff and research institutes), develop individual programs for visiting the objects of the EZ.

Employees of the company are experienced specialists in the Chernobyl accident, ecology, tour- ism, eyewitnesses and liquidators of the accident, who have accumulated a great deal of knowledge about the EZ and related issues. They conduct lectures and trainings on radiation treatment, survival in the event of man-made disasters, organize aviation tours over the EZ (Chernobyl'-tur, 2018). It precents grate interest to the jounalist community, as it is a potentially interesting to the mass media audience, an unusual and vivid news opportunity. They also provide accurate, up-to-date, literally interpreted information on the Chernobyl accident and other man-made disasters and their consequences through their own research unit, presenting it as interesting and accessible (Chernobyl-tur, 2018). It attracts to EZ journalists who are trying to satisfy the interest of their audience to the actual and popular tourist destination.

The task of the Chernobyl-tour agency is also the organization of special events with the participation of mass media. So, on May 20, 2016, a field seminar "Representation of cultural, historical and natural values of the EZ for Ukraine and the world: searching for effective paths and forms" was organized together with the SAUEZM. Journalists from leading tourist mass media were invited to participate as mediators in this process. The event was held in the form of a one-day visit to the EZ on the basis of the standard program of «Chernobyl-tour». To participate in the seminar, each participant was required to pay a registration fee of $300 \mathrm{UAH}$. The program includes the gathering and departure from Kiev, the visit to the most famous locations of the EZ (city of Pripyat, the former secret city of Chernobyl-2, the city of Chernobyl, with a visit to the exhibition exposition of the national culture of the Chernobyl Polissya, opened to the 30th anniversary of the accident, etc.), traditional feeding of the Chernobyl catfishes, lunch in the EZ, professional discussion and coming back to Kiev (Chernobyl-tur, 2018).

«Chernobyl-tour» announces the purpose of its activities as the elimination of information «pollution» in a society that arose after the Chernobyl accident (Chernobyl-tur, 2018). The agency plays an extraordinary role in increasing mass media literacy, and, through the mass media, eliminating the world's ignorance of the disaster-related issues. The unique feature of «Chernobyl-tour» is that the provision of such comprehensive information requires extensive knowledge and experience from various fields, which puts it over the competition in the sphere of organizational and informational service of journalists in the EZ.

The economic aspect of media tourism in the EZ. Understanding and peculiarities of media tourism in the EZ. The materials of the media and the official websites of SAUEZM and «Chernobyl- 
tour» use the terms «press tour», «excursion», «field seminar» to define journalists' visits to the EZ.This, as well as the presence of tourist services for journalists and their integration into the generaltour-ist system of the EZ, gives grounds for classifying it as a type of business tourism - media, that is, connected with the performance of official duties by mass media. At the same time, specific features of the territory determine a certain type of journalist's character. As can be seen from the Table, the voluntary motive of a journalist's visit pre- vails over forced ones. In addition, most voluntary visits are due to the desire to gain their own tourist experience. Journalists arriving at the EZ have specific personality traits. For example, they have strong confidence in the absence of a threat to health $(55 \%)$, developed empathy $(45 \%)$ and imagination of thinking $(45 \%)$. These results make it possible to understand how the professional peculiarities of journalists are related to the choice of the trip and the motivation for it.

Table. The personal and professional features of journalists in the EZ

\begin{tabular}{|c|c|c|c|}
\hline  & $\begin{array}{l}\hat{o}^{2} \\
\infty_{0}^{2} \\
\dot{m}\end{array}$ & $\begin{array}{l}\hat{0}^{2} \\
\infty^{2}\end{array}$ & $\stackrel{\partial}{\sim}$ \\
\hline 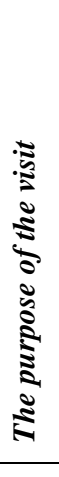 & 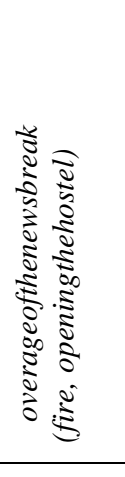 & 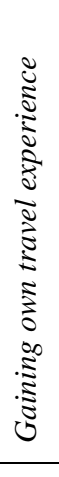 & 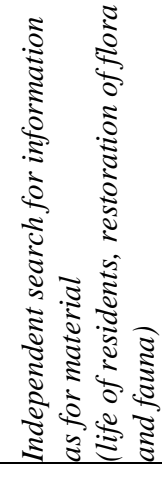 \\
\hline  & $\begin{array}{l}\hat{o}^{2} \\
\hat{n} \\
\dot{m}\end{array}$ & $\frac{80}{6}$ & \\
\hline 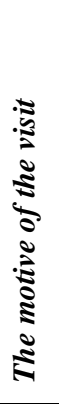 & 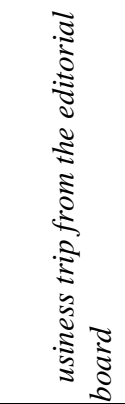 & 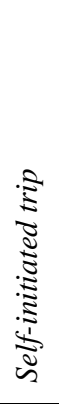 & \\
\hline
\end{tabular}




\begin{tabular}{|c|c|c|c|c|c|c|c|c|c|}
\hline 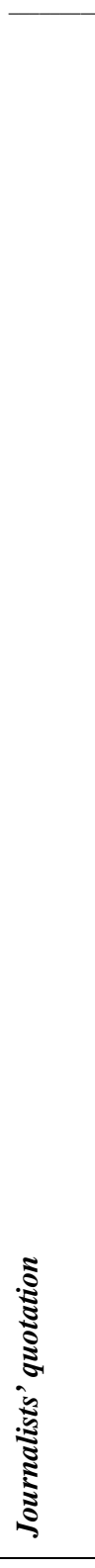 & 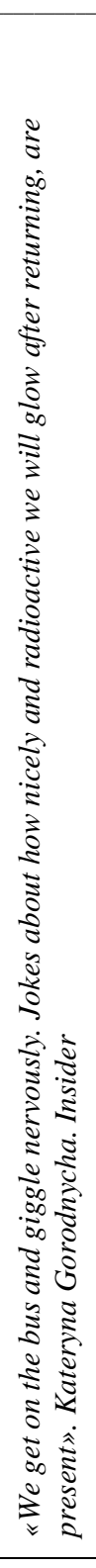 &  & 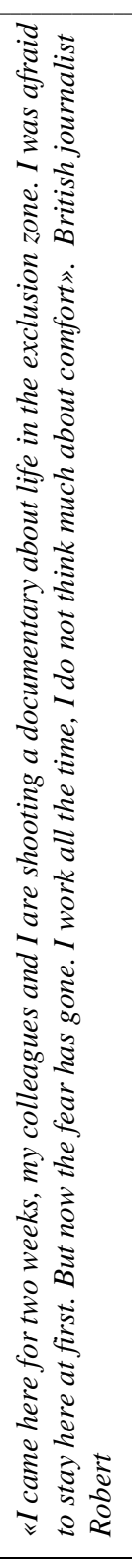 & 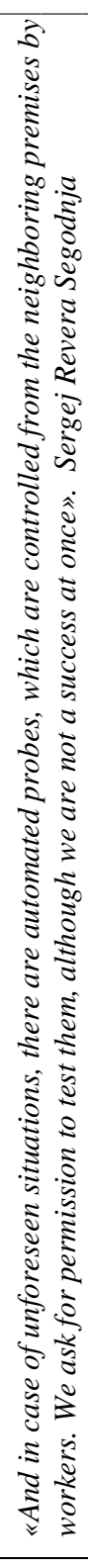 & 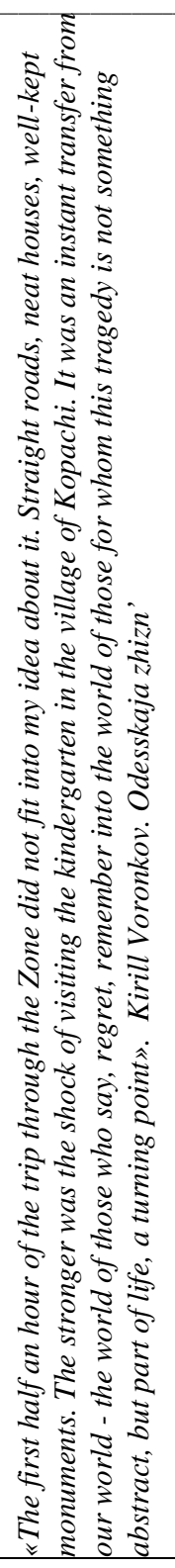 & 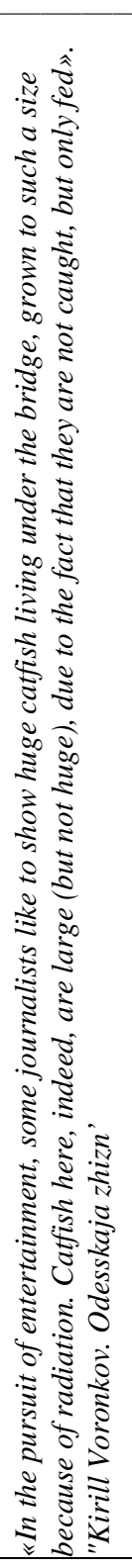 & 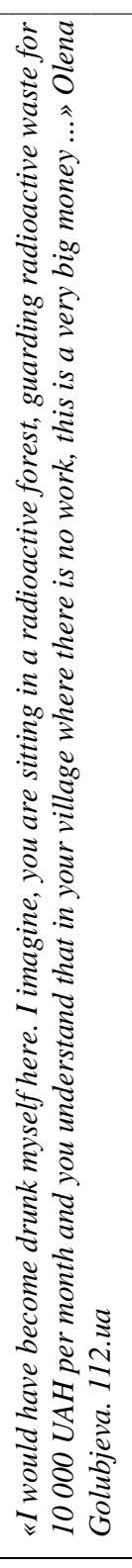 & 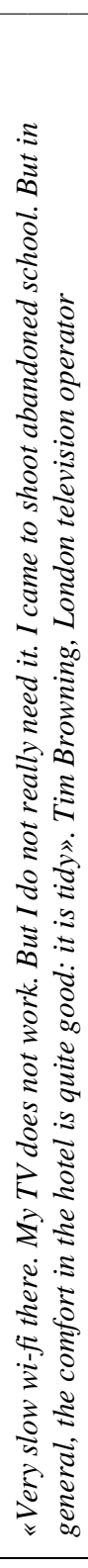 & 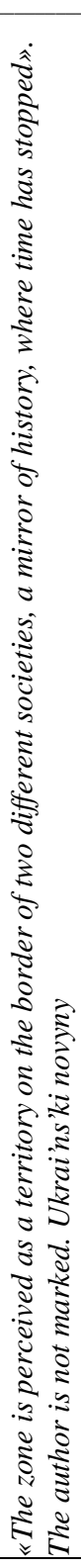 \\
\hline  & $\stackrel{\stackrel{0}{N}}{\stackrel{\sim}{N}}$ & ì & $\stackrel{\circ}{\infty}$ & $\stackrel{\circ}{\infty}$ & $\ddot{\circ}$ & $\stackrel{\stackrel{ }{\sim}}{\sim}$ & $\stackrel{\circ}{\sigma}$ & $\stackrel{\circ}{\infty}$ & $z$ \\
\hline 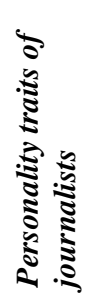 &  & 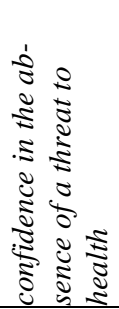 & 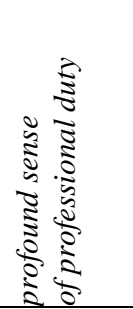 & $\begin{array}{l}0 \\
0 \\
0 \\
0 \\
0\end{array}$ & 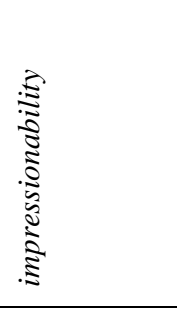 &  & 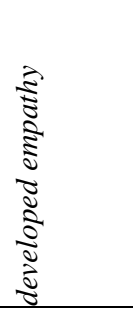 & 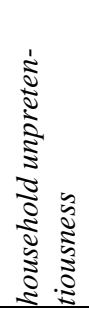 &  \\
\hline
\end{tabular}

The EZ media tourism has the following features:

- deviation from the approved route is prohibited; of the escort; hibited; safety rules are obligatory;

- a pre-authorized permission must be obtained;

- absence of medical contraindications.

In the written request for travel, in addition to personal and contact information, the term and purpose (video, photographing, preparation of report) of staying, the route of visit, the journalist must indicate the nature and extent of the informa- 
tion that he plans to receive; the people with whom he plans to meet. The request is sent by e-mail to the head of SAUEZM at least 10 working days prior to the visit. According to the results of the consideration of the application, permission or motivated refusal are given (Derzhavne agentstvo Ukrai'ny $\mathrm{z}$ upravlinnja zonoju vidchuzhennja, 2018).

Influence of general increase of tourist activity. Every year, tourist flows to the EZ are increasing (Fig.1). At the same time, about $2 / 3$ of tourists are foreigners. Only a year after the com- memoration in 2016, the 30th anniversary of the tragedy, the number of tourists increased by $35 \%$ (by 12977 people). There is a high interest of the world community to the present state of the territory, but not technical innovations in the EZ.In particular, tourists are interested in the changes that took place in the city of Pripyat in the 30 years after the largest man-made disaster in the world and the resettlement of residents (Derzhavne agentstvo Ukrainy $\mathrm{z}$ upravlinnja zonoju vidchuzhennja, 2016).



Fig. 1. Dynamics of tourists' visits in the Chernobyl exclusion zone in 2008-2017, persons (built according to the data of Derzhavne agentstvo Ukrai'ny z upravlinnja zonoju vidchuzhennja, 2017)

Companies that organize visits to the EZ allow the citizens of Ukraine and other countries to receive information on the state of the territory and works on it, in particular, through mass media. Therefore, according to an increase of the total number of tourists, the number of journalists' visits to the EZ increases.A particular increase in journalist activity in this territory is observed during the commemoration of the anniversary of the Chernobyl disaster.

Taking into account the growth of tourist demand, SAUEZM takes measures to form positive public opinion on the radioactive and ecological state of the territory, the work on the elimination of the consequences of the accident and the management of radioactive waste. To improve the quality of tourist service, a secure infrastructure is created, new routes are being developed. Tour operators are invited for a dialogue, competitive working conditions are promised (Derzhavne agentstvo Ukrainy z upravlinnja zonoju vidchuzhennja, 2016). Journal- ists are actively involved to form a positive image of the territory.

The journalists themselves in their materials note that their attention to the territory was attracted by a steady increase of tourist interest to it. Here are some examples of journalist materials.

«In recent years, Ukrainians have increasingly become involved in proposals for domestic tourism. In addition to the "classic» trips to Kiev, Lviv, Odessa and the Carpathians, there are also non-standard offers - a mixture of exotic and extreme tours to the Chernobyl exclusion zone. One-, two- and even three-day tours are offered. I chose for myself a study tour for one day» (Kyryll Voronkov, Odesskaja zhyzn', 2017).

«Every year the zone of exclusion around Chernobyl is becoming an increasingly popular tourist destination. Not only Ukrainians, but also foreigners go there. "Vesti» visited one of these trips and found out what things interested foreign guests in Chernobyl and what they were told by our guides. The most favorite points of the tour pro- 
gram are animals, self-settlers and that disastrous reactor number four. The highlight of the trip is lunch in the canteen in Chernobyl» (Jaroslav Markyn, Vesty, 2017).

«The dummy dressed in protective clothing meets all legal stalkers at the checkpoint «Dityatki». According to the smiling guide, there is a caste of people who visit Chernobyl exactly in this guise, in order to play the role of characters from the famous computer game. This time, shortly before the 32nd anniversary of the catastrophe, the Dnipro journalists decided to check whether it is dangerous for tourists in the 30-kilometer zone, and how Chernobyl catches the souls of visitors» (Kateryna Gacenko, Ruslan Beljavskyj, Nashe mysto, 2018).

Thus, tourists attract journalists' attention to tourist routes in the EZ and force them to describe their tourist experience, and not vice versa. $\mathrm{s}$ it may be seen from fig. 2, an increase in the number of tourists in the EZ leads to a decrease in the number of mass media publications, and vice versa, which we called the «compensation effect». In periods when society is interested in the territory, there is no necessity to attract attention to it in mass media. Reducing the attention of tourists to the territory is compensated by the increased attention of the mass media. The exception is only 2016, when the commemoration of the 30th anniversary of the Chernobyl disaster caused a high interest among both tourists and journalists.

We see a strong positive correlation between the number of visitors to the EZ and the total number of available materials about this territory. The correlation coefficient is 0.8021 at $\mathrm{p}<=$ (less or equal to) 0.05 (Fig. 2). The coefficient is calculated on the assumption that the number of articles for the reporting period can not be considered without previous publications. The previous articles form an information layer that stimulates interest to the territory and the demand of new journalistic materials. The decline in the number of visits in 20142015 is primarily due to a decrease in the level of socio-political stability in Ukraine and a military conflict in the territory of Eastern Ukraine. While the growth of tourist interest in 2015-2016 is associated with a decrease in society's fear of hostilities. This, in turn, attracts the attention of journalists to the territory.



Fig. 2. Interconnection of the number of mass media publications and the number of tourists, units/persons

* materials describing the tourist experience of a journalist for the first 1,000 search queries in Google as of 27.07.2018 Authors' development

Discussion. According to our study, a trip to the EZ requires from journalists such professional qualities as positive world perception;confidence in the absence of a threat to health; profound sense of professional duty; curiosity; impressionability; inclination to sensationalism; developed empathy; household unpretentiousness; imagination of thinking (Table).

The obtained results correlate with the results of research of professional psychological features of representatives of intellectual trades (Tolochek, 2005). According to them, high indicators of im- 
agination of thinking (45\%) and impressionability $(36 \%)$ are explained by the personal qualities of journalists, such as inclination to abstract thinking, emotional sensitivity, sentimentality. At the same time, the focus of journalists on dark tourism can be explained by the breadth of views and radicalism.

The inclination to certain professional activities is explained by the psychotype of the employee (Pittenger, 1993). Journalists belong to the ENFR type - an individual of this type takes an active part in the lives of others, tries new types of activities, is not afraid of difficulties, is inclined to make decisions under the influence of emotions, can not live without dramas and shocks (Krupskyj, 2015). These peculiarities of journalists are explain their developed empathy (compassion and sensitive perception of events), the ease of making a decision to travel to the EZ. At the same time, the tragedy of the history and the gloomy appearance of the territory, the problems of its former and current residents make it attractive to journalists.

An interesting situation arises when a journalist seeks to get into the territory, and then he feels confused by the emotions. Personal interest explains the predominance of the voluntary motive of the trip (61.5\%) over the forced (38.5\%). In this case, the professional and personal components of the trip are balanced (by 38\%): in addition to the curiosity and impressionability of ordinary tourists, journalists have a profound sense of professional duty and a inclination to sensationalism.

The professional interest of journalists in visits to the EZ may be due to their inclination to risk. According to studies conducted by CareerCast, newspaper reporters take the 6th place in the top 10 most stressed professions by 2018 (after a military officer, firefighter, pilot, police officer, coordinator of events) (CareerCast, 2018). Among the causes of stress in this profession, in addition to the hardened deadlines and the fixed attention of society, researchers call the necessity to respond to unexpected risks. In addition, people at risk are more likely to smoke than those who are not at risk (Clifton et al., 2018). Meanwhile, $30 \%$ of male journalists are smokers, female journalists - 27\% (Superjob, 2011).In addition, women are better able to assess the presence of risk in a particular situation, that is explained by their increased vulnerability in comparison with men (Bord, O'Connor, 1997). The impact of this factor on the decision to travel to the contaminated area can explain the results of our study: a slightly smaller number of women journalists in the EZ (46\% of women versus $54 \%$ of men) and a rather high level of confidence in the absence of a threat to health (55\%).

Regulation of media tourism in the CEZ. Provision of tourist services is not provided in the territory of the EZ. Therefore, from the legal point of view, it is expedient to use the term «visit» and not «tourism» (Derzhavne agentstvo Ukrai'ny $\mathrm{z}$ upravlinnja zonoju vidchuzhennja, 2016). This is due to the fact that coming and staying at the territory is limited, and staying without an official permit is prohibited. Hence, fears of public disregard for the provision of commercial services in a territory that was recently the center of a disaster confirms the concept that fear is an obstacle on the way to innovation (Rogers 1995; Hargadon, Douglas, 2001).

In spite of this, in the scientific opinion an approach to visits to the CEZ was formed just like for tourism (Pestushko, Chubuk, 2010; Yankovska G., Hannam K., 2014). During the 1990s, visitors to the territory were exclusively scientists and specialists of the consequences of the accident (Pestushko, Chubuk, 2010). That is why such visits can not be considered as tourism. The beginning of the the real tourism activity in the EZ refers to 2000s, when in 2004 the first official tourist routes were developed.

It means that, despite the apparent development of tourism in the EZ, the emotional bias that existing in the society does not allow recognize it officially. M. Voronov and R. Vince emphasize the inclinatioms of individuals to manifest emotions in response to certain aspects of institutions (Voronov, Vince, 2012), for example, legislative decisions. In this case, such negative aspect is the moral inadmissibility of speculation on the human sorrow.

In favor of asserting that journalists' visits to the EZ are the media tourism, speaks the definition of business tourism to which it belongs. It emphasizes the connection of such trips with business activity: «Business tourism refers to journeys undertaken for work-related purposes» (Davidson, 1994). As our research has shown, despite certain natural limitations, connected with the peculiarity of the territory, the travels of journalists is conditioned by the fulfillment of the professional duties and are carried out within the framework of predrawn up routes. The precence of targeted travel services for journalists and the extensive experience of tourist companies as to their work with mass media in this area make it possible to classify in theory journalists' visits to CEZ as media tourism.

It is impossible to talk about official recognition and legislative consolidation of tourism in the

EZ at this stage. The adoption of such a decision requires the study of emotional obstacles to tourism activities in the EZ and the realization of the ways on their elimination in practice.

The role of media presentation of the territory in promoting dark tourism. According to the founder of the «Chernobyl-tour», Ukraine receives 
about \$ 10 million annually from the inbound tourism in the EZ (Lesiv, 2017). Under such conditions, the development of tourism in this area is of great comer-cial importance for Ukraine. From this point of view, the transformation of the EZ from the tragedy zone into the development zone is the correct strategy for economic growth in the country.

The research confirmed the great importance of the media presentation of the territory in the process of promoting dark tourism and creating its image. The growing influence of media and video games on the development of tourism experience is pointed out (Yankovska, Hannam, 2014). The image of the tourist area, designed by media such as films, television and literature, plays a significant role when choosing a place of rest (Ivashita, 2006). Media presentation affects the perception of tourists of a particular territory and country as a whole. Thus, through the media, it is possible consolidate, enhance and promote very effectively separate images, representations of tourist attractions and their attitudes towards them.

Moreover, media influence the formation of international tourist images (Butler, 1990).Motivational studies have confirmed that a source (media resource) with information about a tourist object can affect the desire of tourists to visit it. To form new objects their images are created and used in popular media. In addition, there is a link between the form of the media, the type of tourist and the characteristics of the object. That is, for the EZ, own means of media promotion in accordance with specific features should be developed.

Connection of the development of media and dark tourism in the EZ. The state should consider the role of the mass media in shaping tourist preferences, creating new tourist objects and their images in the minds of tourists in the development of tourism in the EZ. Such cooperation is of great importance for promoting the region by enhancing its recognition, awareness and involvement of consumers. Insufficient information about tourist opportunities in the region leads to the impossibility of creating attractive image of the territory for potential tourists (Chulov, 2015). It means that the development of tourism in the EZ is significantly dependent on the development of media tourism (Fig. 3).

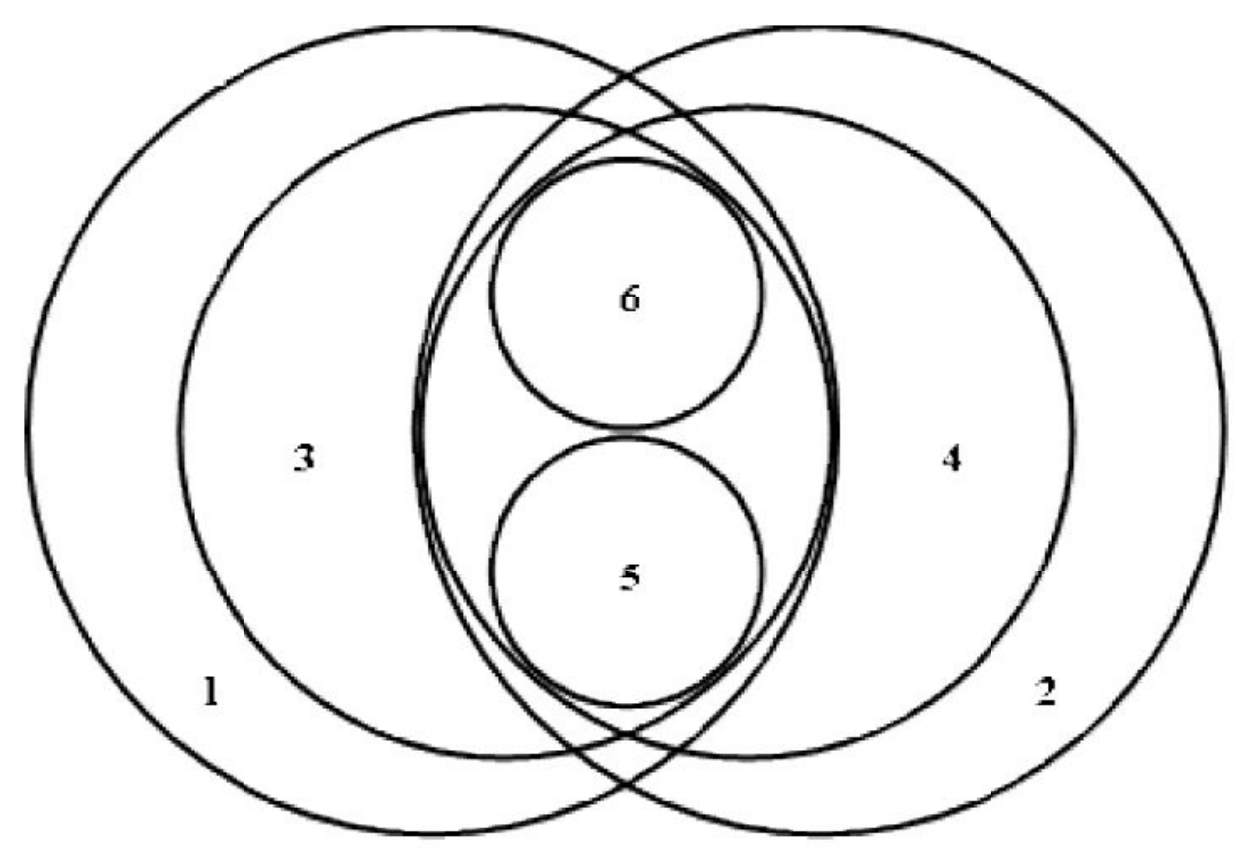

Fig. 3. Connection between dark and media tourism

1 - journalist activity; 2 - dark tourism; 3 - media tourism; 4 - tourism in the CEZ; 5 - editorial business trip; 6 - self-initiated trip uthor's development

Particular attention should be paid to cooperating with foreign mass media (BBC, Discovery, Lonely Planet), since the share of foreign tourists in the EZ annually is about $70 \%$, and their servicing is more profitable than servicing Ukrainians. According to official data, for the preparation of the program for the tourist group, the TISMCEZ receives $2000 \mathrm{UAH}$ from foreign citizens, $495 \mathrm{UAH}$ from the Ukrainian ones. The cost of one-day escort by the responsible person of the TISMCEZ of one foreign citizen is $500 \mathrm{UAH}$, Ukrainian - $140 \mathrm{UAH}$ (Derzhavne agentstvo Ukrainy z upravlinnja zonoju vidchuzhennja, 2016). SAUEZM intends to send all tourism-related activities to the development of the tourist infrastructure of the EZ: improvement of the territory (installation of toilets, tree trimming, garbage gathering, creation of cafes and other 
events) (Derzhavne agentstvo Ukrainy z upravlinnja zonoju vidchuzhennja, 2016).

It is necessary to continue developing a state strategy for coverage of the CEZ in the world mass media, which would contribute to the formation of a positive image of the territory and tourist preferences in this direction. One of the steps of this strategy is to formulate the essence of the brand: holding special bright cultural events, attracting attention to unusual historical values, monuments, facts, events, etc. (Smirnova, Privarnikova, 2015). It is expedient to develop special tourism programs, to conduct regular excursions and seminars for journalists, to cooperate with mass media on content production to attract tourists from their audience - documentaries and feature films, television special projects, and other media support tools. In addition, information about the region should be submitted in detail, emotionally, personally and regularly (Chulov, 2015).

Cultural aspect of media tourism in the EZ. The local government should engage in public dialogue to explain the benefits of developing dark tourism and help it in the decision-making process (Kim, Butler, 2015). This work is of particular importance in the conditions of polarization of public opinion on the ethics of the development of such tourism, which took place in Snowtown (Southern Australia) (Kim, Butler, 2015). The overwhelming majority of local "long-livers" was against the exploitation of recent criminal events in the city to attract tourists. While other residents, especially those who arrived in the city after the arrest of the murderous killers in Snowtown (after 1999), supported this idea.In the Ukrainian society, there is also a problem of the ethics of such tourism in relation to the Chernobyl veterans and victims of the disaster. Also, despite the explanatory work, there are biases regarding the environmental and radiation hazards of the territory. The elimination of these obstacles can be achieved by dialogue with the public through the Ukrainian and world mass media.

It should take into account the attitude of journalists themselves to the development of dark tourism, which they cover and to which their publications contribute. The professional duty of journalists makes them cover all relevant social phenomena such as tourism in the EZ even if it is harmful for their health. This allows them to work in the most unfavorable conditions - in any area where there is a risk or danger to health and life. This can also explain such a feature of journalists in the

$\mathrm{EZ}$, as profound sense of professional duty (Table).

The feature of the EZ is not only the personal attitude of the journalist to the work, but also his fear of his health after the trip. If the work at hot spots has a risk of injury or death, then work at the

EZ - the risk of radiation exposure in case of deviation from the route and violation of safety rules (Derzhavne agentstvo Ukrai'ny z upravlinnja zonoju vidchuzhennja, 2014). As our study showed, journalists have a confidence in the radioactive safety of the territory of the EZ (Table). Professional characterological features allow them to ignore those aspects of information that can be perceived by others as negative. On the contrary, they have positive view of the phenomena they have to deal with in their professional activities. Such an attitude is one of the mechanisms of psychological protection in condi-tions of increased stress in the profession. Thus, the psychological peculiarities of world perception allow journalists to overcome successfully the specific barriers that distinguish the work of the EZ from work in other territories.

Recommendations for future researchers. The research showed that the motivation for journalists' visits to the EZ is business trip for covering newsbreak and looking for information as for publications on the state of the territory (including tourist routes). However, in the course of the study, the authors had a hypothesis about monetary reward as one of the main motivations of a journalist's visit to the EZ. It needs to be checked in further research. To do this, it is necessary to create a database of journalists who visited the EZ, indicating their contact details, and conduct questionnaires and interviews. Among other issues, it is necessary to develop the presence/absence of material incentives and rewards for such journalists for work in a radioactive contaminated area.

In order to solve the problem of the ethical aspect of media tourism, it is necessary during the interview to find out the personal attitude of journalists to performing such a kind of work. It should be taken into account, which part of those who visited the EZ, felt internal discomfort before, during and after the trip. It is also necessary to determine how many journalists refused the proposed trip and for what reasons (fear for the state of health, ethical beliefs, etc.).

Conclusions. In our study, we were able to describe a new phenomenon of media tourism in the Chernobyl Exclusion Zone and to establish its peculiarities. Journalists traveling to the Chernobyl Exclusion Zone have specific personality traits. The most striking of them is confidence in the absence of risk, ability to empathize and imaginative thinking. Thus, the tragedy of history and the gloomy appearance of the territory, the suffering of its residents make it attractive for journalists. Personal interest explains the predominance of the voluntary motive of traveling over forced ones. Positive 
world perception and sense of professional duty allows journalists to ignore such features of the territory as the risk of radiation exposure and the problem of ethics. At the same time, the prevalence among them of male journalists is due to their lower ability to assess risk. The attention of journalists to the territory is attracted by the activity of tourists on it.There is a phenomenon of the so-called «compensation effect», when the reduction of tourists' attention to the territory is com-pensated by an increase in the attention of the mass media.

The organization of visits of journalists contributes to the formation of a positive image of the territory and the elimination of «information» pollu-tion. It is important to make cooperation with mass media a key element of the strategy of developing the tourist potential of this territory. At the same time, this work should be considered not only as an instrument of promotion, but also in terms of the prospects of media tourism. Further research will be devoted to the search for strategic directions for the promotion of media tourism in the Chernobyl Exclusion Zone.

\section{References}

Alvesson M., Kärreman D., 2007. Constructing mystery: Empirical matters in theory development. The Academy of Management Review, 32(4). 12651281. doi:10.5465/amr.2007.26586822

Bord, R. J., O’Connor, R. E., 1997. The gender gap in environmental attitudes: the case of perceived vulnerability to risk. Social Science Quarterly, 78(4), 830-840.

Butler R. W., 1990. The Influence of the Media in Shaping International Tourist Patterns. Tourism Recreation Research, 15(2), 46-53. doi:10.1080/02508281.1990.11014584.

Careercast, 2018. The Most Stressful Jobs of 2018. Careercast. Retrieved from URL: https://www.careercast.com/jobs-rated/2018most-stressful-jobs?page $=0 \quad$ Available at 17.04.2018.

Chernobyl'-tur. [Chernobyl tour]. Retrieved from URL: https://www.chernobyl-tour.com/index.php

Chulov D. A., 2015. Brending i territorial'noe razvitie v turizme: vzaimodejstvie so SMI i potrebitelem [Branding and territorial development in tourism: interaction with mass media and a consumer], Services in Russia and Abroad, 5, 140-157. doi: 10.12737/ 17471. (In Russian).

Clifton E. A., Perry J. R., Imamura F., Lotta L. A., Brage S., Forouhi N. G., Griffin S. J., Wareham N. J., Ong K. K. , Day F.R., 2018. Genome-wide association study for risk taking propensity indicates shared pathways with body mass index. Communications Biology, 1(1), 1-10. doi:10.1038/s42003-018-0042-6

Davidson R., 1994. Business Travel. London. Addison Wesley Longman
Derkach U., 2014. Osoblyvosti organizacii' turyzmu tehnogennyh katastrof $\mathrm{v}$ Ukrai'ni [Features of man-made disasters tourism in Ukraine]. Visn. of the Lviv Univ. Series international relations, 34, 56-66 (In Ukrainian).

Derzhavne agentstvo Ukrai'ny $\mathrm{z}$ upravlinnja zonoju vidchuzhennja (DAZV) [State agency of Ukraine on Exclusion zone management (SAUEZM)]. Retrieved from URL: http://dazv.gov.ua.

Eisenhardt, K. M., 1989. Building theories from case study research. Academy of Management Review, 14(4), 532-550. doi:10.5465/amr.1989.4308385.

Foley M., Lennon J. J., 1996. JFK and dark tourism: A fascination with assassination. International Journal of Heritage Studies, 2(4), 198-211. doi: 10.1080/13527259608722175.

Forbes, 2009. In Pictures: World's Most Unique Places To Visit. Forbes. Retrieved from URL: https://www.forbes.com/2009/11/04/uniquevacations-travel-lifestyle-travel-adventuretourism_slide/. Available at 17.04.2018.

Gacenko E., Beljavskij R., 2018. Gorod-prizrak i atmosfera smerti: kakie tajny skryvaet zlopoluchnaja Chernobyl'skaja zona . [Ghost city and the atmosphere of death: what secrets the disastrous Chernobyl zone hides]. Retrieved from URL: http://nashemisto.dp.ua/2018/04/26/gorodprizrak-i-atmosfera-smerti-kakie-tajny-taitzlopoluchnaya-chernobylskaya-zona-foto/ (in Russian). Available at 17.04.2018.

Goleva O. P., 2015. Celevye auditoria ivent-marketinga i vidy sobytijnyh meroprijatij [The target audience of event marketing and types of events]. Vestn. MGUP by Ivan Fedorov, 4, 22-24. (In Russian).

Golovata L., 2010. Chornobylski stalkery [Chernobyl stalkers]. Zaxid.net. Retrieved from URL: https://zaxid.net/chornobilski_stalkeri_n1101343 (in Ukrainian).

Hargadon, A., Douglas, Y., 2001. When innovations meet institutions: Edison and the design of the electric light. Administrative Science Quarterly, 46(3), 476-501. doi:10.2307/3094872.

Iwashita C., 2006. Media representation of the UK as a destination for Japanese tourists: Popular culture and tourism. Tourist Studies, 6(1), 59-77. doi:10.1177/1468797606071477.

Kim H., Richardson S. L., 2003. Motion picture impacts on destination images. Annals of Tourism Research, 30(1), 216-237. doi:10.1016/S01607383(02)00062-2.

Kim S., Butler G., 2015. Local community perspectives towards dark tourism development: The case of Snowtown, South Australia. Journal of Tourism and Cultural Change, 13(1), 78-89. doi:10.1080/14766825.2014.918621.

Krups'kyj O. P., 2015. The cognitive style as a factor of the development of tourism and hospitality enterprises. Problems of the economy, (2), 140-146. http://doi.org/10.5281/zenodo.1323421. (in Ukrainian)

Kuz'mych-Pohodenko A. S., 2015. Problema Chornobylja u publicystyci Liny Kostenko [Problem of 
Chernobyl in Lina Kostenko'spublicism]. «Young scientist», 12(27), 150-153. (in Ukrainian).

Lesiv M., 2017. Tury v Chernobyl' prinosjat Ukraine million dollarov [Tours to Chernobyl bring Ukraine millions of dollars]. Public people. Retrieved from URL: https://pl.com.ua/tury-vchernobyl-prinosyat-ukraine-milliony-dollarov/ (In Russian).

Lincoln Y. S., Guba E. G. (1985) Naturalistic Inquiry. Beverly Hills, CA: SAGE.

Markin Ja., 2017. Pushka i gosti iz Kanady: chto inostrancam rasskazyvajut o Chernobyle. [Cannon and guests from Canada: what is told to forigners about Chornobyl]. Retrieved from URL: https://vesti-ukr.com/strana/241753-chtoinostrantsam-rasskazyvajut-o-chernobyle- (in Russian). Available at 17.04.2018.

Pestushko V. Ju, Chubuk Ju. P., 2010. Chornobyl's'ka AES jak turystychna destynacija. [Chernobyl atomic electric power station as tourist destination]. Geography and Tourism, 9, 82-86. (In Ukrainian).

Pittenger, D. J., 1993. Measuring the MBTI... and coming up short. Journal of Career Planning and Employment, 54(1), 48-52.

Rogers, E. M. 1995. Diffusion of innovations (4th ed.). New York. Simon and Schuster.

Smirnova, T., Privarnikova, I., 2015. Formation of the brand the city as an innovative way to improve its attractiveness for tourism. European Journal of Management Issues, 23(5), 93-100. doi:10.15421/191526 (in Ukrainian).
Superjob, 2011. Sredi brosivshih kurit' lidirujut jekologi. [Among those who quit smoking, ecologists are leading]. Superjob. Retrieved from URL: https://www.superjob.uz/community/life/52442/ (in Russian). Available at 17.04.2018.

Tolochek V. A., 2005. Sovremennaja psihologija truda [Modern psychology of work]. Peter, Saint Petersburg (in Russian).

Voronkov K., 2017. Chto odesskij zhurnalist uvidel v zone otchuzhdenija Chernobyl'skoj AJeS? [What did the journalist from Odessa see in the zone of exclusion of the Chernobyl nuclear power plant ?]. Retrieved from URL: http://odessalife.od.ua/article/8143-Chto-odesskiy-zhurnalistuvidel-v-zone-otchuzhdeniya-ChernobylskoyAES (in Russian). Available at 17.04.2018.

Voronov, M., Vince, R., 2012. Integrating Emotions into Analysis of Institutional Work. Academy of Management Review, 37(1), 58-81. doi:10.5465/armr.2010.0247

Yankovska G., Hannam K., 2014. Dark and toxic tourism in the Chernobyl exclusion zone. Current Issues in Tourism, 17(10), 929-939. doi:10.1080/13683500.2013.820260.

Yin, R., 2009. Case study research: Design and methods (4th ed.). Los Angeles Calif., Sage Publications.

Young A. F., Young R., 2008. Measuring the Effects of Film and Television on Tourism to Screen Locations: A Theoretical and Empirical Perspective. Journal of Travel \& Tourism Marketing, 24(2-3), 195-212. doi:10.1080/10548400802092742. 